\title{
New Cadinene Sesquiterpenoids from the Formosan Soft Coral Xenia puerto-galerae
}

\author{
Chang-Yih Duh, ${ }^{*}+$ Shih-Chao Chien, ${ }^{\dagger}$ Pei-Ying Song, ${ }^{\dagger}$ Shang-Kwei Wang, ${ }^{\ddagger}$ Ali Ali H. El-Gamal, ${ }^{\dagger}$ and \\ Chang-Feng Dai ${ }^{\S}$
}

Department of Marine Resources, National Sun Yat-sen University, Kaohsiung, Taiwan, Department of Microbiology, Kaohsiung Medical University, Kaohsiung, Taiwan, and Institute of Oceanography, National Taiwan University, Taipei, Taiwan, Republic of China

Received J uly 18, 2002

Six new cadinene sesquiterpenoids, xenitorins $A-F(\mathbf{1}-\mathbf{6})$, were isolated from the methylene chloride solubles of the Formosan soft coral Xenia puerto-galerae. The structures were elucidated by 1D and 2D NMR spectral analysis, and their cytotoxicity against selected cancer cells was measured in vitro.

Thesoft coral s of thegenus Xenia arerich in terpenoids ${ }^{1-19}$ and steroids. ${ }^{20}$ As part of our search for bioactive substances from marine organisms, the Formosan soft coral Xenia puerto-gal erae Roxas (family Xeniidae) was studied because $\mathrm{CH}_{2} \mathrm{Cl}_{2}$ extracts showed significant cytotoxicity values to A549 (human lung adenocarcinoma), HT-29 (human colon adenocarcinoma), and P-388 (mouse lymphocytic leukemia) cell cultures as determined by standard procedures. ${ }^{21,22}$ Bioassay-guided fractionation resulted in the isolation of six new cadinene sesquiterpenoids, xenitorins $A-F(\mathbf{1}-\mathbf{6})$. Xenitorins $A-B$ and xenitorins $D-F$ contain an oxygen functionality at $C-8$, which is a previously unrecognized site of oxidation in cadinene sesquiterpenoids. Xenitorin A exhibited cytotoxicity against A-549 cells. Xenitorin E showed cytotoxicty against P-388 and A-549 cells.<smiles>C=C(C)C1C(O)C=C(C)C2CCC(C)CC21</smiles><smiles>C=C(C)[C@H]1C(=O)C=C(C)[C@H]2CC[C@H](C)C[C@@H]21</smiles><smiles>C=C(C)C1C=C[C@H](C)[C@H]2CC[C@H](C)C[C@H]12</smiles>

3<smiles>C=C(C)C1C(=O)C=C(C)[C@]2(O)CC[C@@H](C)C[C@H]12</smiles>

5

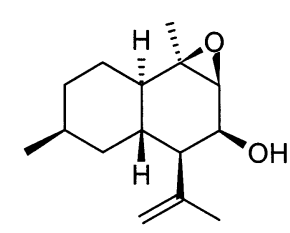

4

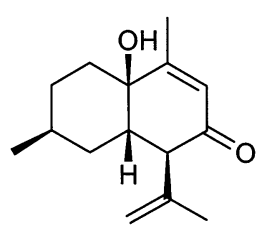

6
* To whom correspondence should be addressed. Tel: 886-7-525-2000, ext. 5036. Fax: 886-7-525-5020. E-mail: yihduh@mail.nsysu.edu.tw.

+ National Sun Yat-sen University.

‡ Kaohsiung Medical University.

$\S$ National Taiwan University.

\section{Results and Discussion}

Xenitorin A (1) was isolated as a colorless oil. HREIMS, ${ }^{13} \mathrm{C}$ NMR, and DEPT spectra established the molecular formula of $\mathbf{1}$ as $\mathrm{C}_{15} \mathrm{H}_{24} \mathrm{O}$. Thus, four degrees of unsaturation were determined for $\mathbf{1}$. The presence of a secondary hydroxyl group in 1 was indicated by IR $\left(3400 \mathrm{~cm}^{-1}\right)$ and NMR data $\left(\delta_{\mathrm{H}} 3.92 \mathrm{br} s ; \delta_{\mathrm{C}} 64.5 \mathrm{~d}\right)$ ). The presence of four $\mathrm{sp}^{2}$-hybridized carbon atoms in the molecule, as deduced from the ${ }^{13} \mathrm{C}$ and DEPT NMR spectra (Table 2), corresponding to two carbon-carbon double bonds as the only multiple bonds, indicated compound $\mathbf{1}$ to be bicyclic. The ${ }^{13} \mathrm{C}$ NMR singlet at $\delta 141.8$ and a doublet at $\delta 122.7$ that was correlated in the HMBC experiment (Figure 1) with the ${ }^{1} \mathrm{H}$ NMR signal at $\delta 5.66(\mathrm{dq}, \mathrm{J}=1.0,3.0 \mathrm{~Hz}, 1 \mathrm{H})$ together with the vinylic methyl signals at $\delta 1.71(\mathrm{~d}, \mathrm{~J}=$ $1.0 \mathrm{~Hz}, 3 \mathrm{H}$ ) in the ${ }^{1} \mathrm{H}$ NMR spectrum and at $\delta 20.9$ (q) in the ${ }^{13} \mathrm{C}$ NMR spectrum were assigned to a Z-trisubstituted double bond bearing a methyl group. HMQC correlation of $\delta_{\mathrm{H}} 4.71(\mathrm{~s}, 1 \mathrm{H})$ and $5.11(\mathrm{~s}, 1 \mathrm{H})$ with $\delta_{\mathrm{C}} 113.4(\mathrm{t})$ as well as HMBC correlation of these two protons with $\delta_{\mathrm{C}} 144.8$ (s), 24.1 (q), and 53.0 (d) indicated that 1 contained an isopropenyl group. NMR also showed the presence of a secondary methyl $\left(\delta_{\mathrm{H}} 0.98 \mathrm{~d} ; \delta_{\mathrm{C}} 18.3\right)$, three methylenes $\left(\delta_{\mathrm{C}} 24.4,32.4,35.6\right)$, and four methines $\left(\delta_{\mathrm{C}} 27.8,53.0,47.1\right.$, 30.2). Measurement of the ${ }^{13} \mathrm{C}-{ }^{13} \mathrm{C}$ homonuclear shift correlation 2D spectrum (INADEQUATE) of $\mathbf{1}$ together with COSY (Figure 1), HMQC, and HMBC experiments established its chemical structure and enabled also the assignment of all resonances in the NMR spectra. The relative stereochemistry of $\mathbf{1}$ was deduced from a 2D NOESY experiment (Figure 2), which indicated that $\mathrm{Me}-$ $11, \mathrm{H}-6, \mathrm{H}-2 \beta$, and $\mathrm{Me}-14$ were on one side of the molecule, while $\mathrm{H}-1, \mathrm{H}-3 \alpha, \mathrm{H}-5 \alpha, \mathrm{H}-7$, and $\mathrm{H}-8$ were on the opposite side of the molecule. From the aforementioned data, xenitorin A can be formulated as $\mathbf{1}$.

Xenitorin B (2) was isolated as a colorless amorphous solid, whose molecular formula, $\mathrm{C}_{15} \mathrm{H}_{22} \mathrm{O}$, was revealed by HREIMS and NMR spectra. The IR and UV spectra showed the presence of an $\alpha, \beta$-unsaturated ketone $\left(1657 \mathrm{~cm}^{-1} ; 239\right.$ $\mathrm{nm}$ ) moiety. The ${ }^{13} \mathrm{C}$ NMR features (Table 2) of $\mathbf{2}$ were closely related to those of $\mathbf{1}$ except in the vicinity of the carbonyl in 2. The only difference was the secondary hydroxyl at C-8 in $\mathbf{1}$ was replaced by a ketone in $\mathbf{2}$. HMBC correlations from $\mathrm{H}-7$ to $\mathrm{C}-8, \mathrm{C}-6, \mathrm{C}-1, \mathrm{C}-14$ and from $\mathrm{H}-15$ to $C-9, C-10, C-1$ confirmed the position of the ketone in $\mathbf{2}$. The relative stereochemistry of $\mathbf{2}$ was deduced from 2D NOESY experiment (Table 4), which indicated that Me- 
Table 1. ${ }^{1} \mathrm{H}$ NMR Data ${ }^{\mathrm{a}}$ of $1-6$

\begin{tabular}{|c|c|c|c|c|c|c|}
\hline $\mathrm{H}$ & 1 & 2 & 3 & 4 & 5 & 6 \\
\hline 1 & 1.59 br d (13.0) & $2.03 \mathrm{~m}$ & $1.17 \mathrm{~m}$ & $1.30 \mathrm{~m}$ & & \\
\hline $2 \alpha$ & $1.84 \mathrm{~m}$ & $1.98 \mathrm{~m}$ & $1.79 \mathrm{~m}$ & $1.80 \mathrm{dq}(13.0,2.8)$ & $1.88 \mathrm{dt}(14.0,2.6)$ & $1.72 \mathrm{dt}(4.8,14.0)$ \\
\hline $2 \beta$ & $1.26 \mathrm{~m}$ & $2.38 \mathrm{~m}$ & $1.62 \mathrm{~m}$ & $1.44 \mathrm{qd}(4.0,12.5)$ & 1.64 td $(14.0,4.8)$ & $1.90 \mathrm{br} d(14.0)$ \\
\hline $3 \alpha$ & $1.56 \mathrm{~m}$ & $1.65 \mathrm{~m}$ & $1.56 \mathrm{~m}$ & $1.58 \mathrm{~m}$ & $1.95 \mathrm{dt}(14.0,4.8)$ & 1.54 br d (13.0) \\
\hline $3 \beta$ & $1.58 \mathrm{~m}$ & $1.66 \mathrm{~m}$ & $1.58 \mathrm{~m}$ & $1.60 \mathrm{~m}$ & $1.48 \mathrm{dq}(14.0,2.6)$ & $1.26 \mathrm{~m}$ \\
\hline 4 & $2.04 \mathrm{~m}$ & $2.08 \mathrm{~m}$ & $1.98 \mathrm{~m}$ & $2.01 \mathrm{~m}$ & $2.08 \mathrm{~m}$ & $1.63 \mathrm{~m}$ \\
\hline $5 \alpha$ & $1.06 \mathrm{dt}(4.0,13.0)$ & $1.30 \mathrm{~m}$ & $1.10 \mathrm{dt}(4.5,12.5)$ & $1.55 \mathrm{br} d(14.0)$ & $1.69 \mathrm{td}(13.5,4.5)$ & $1.64 \mathrm{~m}$ \\
\hline $5 \beta$ & $1.84 \mathrm{~m}$ & $2.03 \mathrm{~m}$ & $1.71 \mathrm{~m}$ & $1.02 \mathrm{~m}$ & $1.27 \mathrm{~m}$ & $1.20 \mathrm{~m}$ \\
\hline 6 & 1.80 td $(13.1,3.0)$ & 1.49 br d (14.0) & $1.65 \mathrm{~m}$ & $1.61 \mathrm{~m}$ & 2.20 td $(12.6,3.0)$ & $2.90 \mathrm{br} \mathrm{d}(14.0)$ \\
\hline 7 & $1.99 \mathrm{dd}(3.5,12.0)$ & $2.70 \mathrm{~d}(12.5)$ & $2.38 \mathrm{dt}(9.5,2.0)$ & 1.73 br d (8.5) & $3.07 \mathrm{~d}(12.6)$ & $3.26 \mathrm{~d}(14.0)$ \\
\hline 8 & $3.92 \mathrm{br} \mathrm{s}$ & & $5.49 \mathrm{dd}(2.0,10.0)$ & $4.04 \mathrm{dt}(8.5,4.2)$ & & \\
\hline 9 & $5.66 \mathrm{dq}(3.0,1.0)$ & $5.92 \mathrm{q}(1.0)$ & $5.70 \mathrm{dd}(2.0,10.0)$ & $3.24 d(5.5)$ & $5.87 q(1.0)$ & $5.95 \mathrm{~s}$ \\
\hline 11 & $0.98 d(7.0)$ & $0.98 \mathrm{~d}(7.0)$ & $0.97 \mathrm{~d}(7.5)$ & $0.98 d(7.5)$ & $1.00 \mathrm{~d}(7.0)$ & $0.90 \mathrm{~d}(6.5)$ \\
\hline $13 z$ & $4.71 \mathrm{~s}$ & $4.78 \mathrm{~s}$ & $4.74 \mathrm{~d}(1.5)$ & $4.69 \mathrm{~s}$ & $4.83 \mathrm{~s}$ & $4.87 \mathrm{~s}$ \\
\hline $13_{\mathrm{E}}$ & $5.11 \mathrm{~s}$ & $5.03 \mathrm{~s}$ & $4.80 \mathrm{~d}(1.0)$ & $4.94 \mathrm{~s}$ & $5.05 \mathrm{~s}$ & $5.08 \mathrm{~s}$ \\
\hline 14 & $1.79 \mathrm{~s}$ & $1.59 \mathrm{~s}$ & $1.60 \mathrm{~s}$ & $1.76 \mathrm{~s}$ & $1.57 \mathrm{~s}$ & $1.66 \mathrm{~s}$ \\
\hline $\begin{array}{l}15 \\
\mathrm{OH}\end{array}$ & $1.71 \mathrm{~d}(1.0)$ & $1.93 \mathrm{~d}(1.0)$ & $1.26 \mathrm{~s}$ & $1.33 \mathrm{~s}$ & $1.99 \mathrm{~d}(1.0)$ & $2.05 \mathrm{~s}$ \\
\hline $\mathrm{OH}-8$ & & & & $2.12 \mathrm{~d}(8.5)$ & & (כ. \\
\hline
\end{tabular}

a Recorded in $\mathrm{CDCl}_{3}$ at $500 \mathrm{MHz}$.

Table 2. ${ }^{13} \mathrm{C}$ NMR Spectral Data ${ }^{a}(\delta)$ of $\mathbf{1}-\mathbf{6}$ in $\mathrm{CDCl}_{3}$

\begin{tabular}{rrrrrrr}
\hline & $\mathbf{1}$ & $\mathbf{2}$ & \multicolumn{1}{c}{$\mathbf{3}$} & $\mathbf{4}$ & $\mathbf{5}$ & \multicolumn{1}{c}{$\mathbf{6}$} \\
\hline 1 & 47.1 & 45.7 & 47.6 & 47.2 & 84.0 & 70.1 \\
2 & 24.4 & 23.6 & 18.9 & 21.9 & 29.1 & 29.4 \\
3 & 32.4 & 31.8 & 31.4 & 32.0 & 29.8 & 26.3 \\
4 & 27.8 & 26.8 & 27.2 & 27.6 & 25.1 & 26.1 \\
5 & 35.6 & 36.7 & 37.0 & 36.1 & 31.7 & 31.1 \\
6 & 30.2 & 36.6 & 29.4 & 26.2 & 36.7 & 37.9 \\
7 & 53.0 & 62.3 & 52.7 & 53.7 & 57.1 & 56.4 \\
8 & 64.5 & 198.8 & 132.6 & 67.0 & 197.6 & 198.6 \\
9 & 122.7 & 127.3 & 134.6 & 62.6 & 128.5 & 127.9 \\
10 & 141.8 & 164.0 & 68.6 & 62.5 & 164.9 & 161.6 \\
11 & 18.3 & 17.8 & 17.6 & 18.1 & 22.1 & 17.3 \\
12 & 144.8 & 141.3 & 146.6 & 144.4 & 140.7 & 140.4 \\
13 & 113.4 & 116.7 & 112.8 & 114.2 & 117.1 & 117.4 \\
14 & 24.1 & 18.5 & 18.9 & 22.5 & 18.3 & 18.4 \\
15 & 20.9 & 21.5 & 27.3 & 20.5 & 18.0 & 18.6 \\
\hline
\end{tabular}

a Recorded in $\mathrm{CDCl}_{3}$ at $75 \mathrm{MHz}$ (assigned by DEPT, COSY, HSQC, and HMBC experiments).
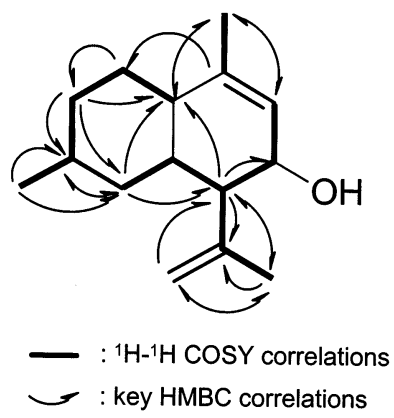

Figure 1. COSY and $\mathrm{HMBC}$ correlations of $\mathbf{1}$.

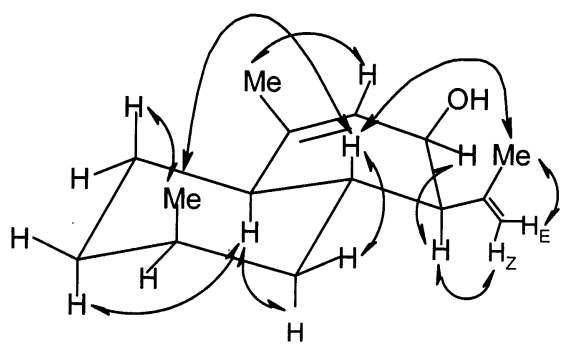

Figure 2. Selected NOESY correlations of $\mathbf{1}$.

$11, \mathrm{H}-6, \mathrm{H}-2 \beta$, and $\mathrm{Me}-14$ were on one side of the molecule, while $\mathrm{H}-1, \mathrm{H}-3 \alpha$, and $\mathrm{H}-5 \alpha$ were on the opposite side of the molecule. From the aforementioned data, xenitorin $\mathrm{B}$ can be formulated as $\mathbf{2}$.
Xenitorin C (3) was isolated as a colorless oil and analyzed for $\mathrm{C}_{15} \mathrm{H}_{24} \mathrm{O}$ by HREIMS and NMR spectral data (Tables 1 and 2). Spectroscopic data of $\mathbf{3}$ were analogous to those of $\mathbf{1}$ with the exception that the resonances for the methyl-bearing trisubstituted ol efin and the secondary hydroxyl were replaced by a disubstituted olefin and a methyl-bearing tertiary hydroxyl. HMBC correlations (Table 3) from $\mathrm{H}-15$ to $\mathrm{C}-1, \mathrm{C}-9$, and $\mathrm{C}-10$; from $\mathrm{H}-9$ to $\mathrm{C}-8$ and C-7; and from $\mathrm{H}-8$ to $\mathrm{C}-7$ and $\mathrm{C}-9$ clearly positioned the disubstituted ol efin and the tertiary hydroxyl. The relative stereochemistry of $\mathbf{3}$ was deduced from a 2D NOESY experiment (Figure 3), which indicated that $\mathrm{Me}-11, \mathrm{H}-6$, $\mathrm{H}-2 \beta$, and $\mathrm{Me}-14$ were on one side of the molecule, while $\mathrm{Me}-15, \mathrm{H}-1, \mathrm{H}-3 \alpha, \mathrm{H}-5 \alpha$, and $\mathrm{H}-7$ were on the opposite side of the molecule. The structure of xenitorin $C$ is thus formulated as $\mathbf{3}$.

Xenitorin $\mathrm{D}(\mathbf{4})$ was isol ated as a colorless oil of molecular formula $\mathrm{C}_{15} \mathrm{H}_{24} \mathrm{O}_{2}$, as indicated by HREIMS and ${ }^{13} \mathrm{C} N M R$ (Table 2) spectral methods. The NMR features of $\mathbf{4}$ were also analogous to those of $\mathbf{1}$. Analyses of 2D NMR data revealed that $\mathbf{4}$ possessed the same carbocydic skel eton as 1. However, there was a significant difference that indicated the presence of a methyl-bearing trisubstituted epoxide $\left[\delta_{\mathrm{C}} 20.5(\mathrm{q}), 62.5\right.$ (s), 62.6 (d)] in 4 instead of a methyl-bearing trisubstituted olefin in $\mathbf{1}$. HMBC correlations (Table 3) between $\mathrm{H}-15$ and $\mathrm{C}-1, \mathrm{C}-9$, and $\mathrm{C}-10$ and between $\mathrm{H}-9$ and C-15, C-10, C-8 clearly positioned the methyl-bearing trisubstituted epoxide. The relative stereochemistry of $\mathbf{4}$ was deduced from a 2D NOESY experiment (Figure 4), which indicated that $\mathrm{Me}-11, \mathrm{H}-6, \mathrm{H}-2 \beta, \mathrm{OH}-8$, and $\mathrm{Me}-14$ were on one side of the molecule, while Me-15, $\mathrm{H}-1, \mathrm{H}-3 \alpha, \mathrm{H}-5 \alpha, \mathrm{H}-8, \mathrm{H}-9$, and $\mathrm{H}-7$ were on the opposite side of the molecule. The structure of xenitorin $\mathrm{D}$ is thus formulated as 4.

Xenitorin $\mathrm{E}$ (5) was analyzed for $\mathrm{C}_{15} \mathrm{H}_{22} \mathrm{O}_{2}$ by HREIMS and NMR spectral data. The IR and UV spectra showed the presence of an $\alpha, \beta$-unsaturated ketone $\left(1650 \mathrm{~cm}^{-1} ; 237\right.$ $\mathrm{nm})$ and hydroxyl $\left(3400 \mathrm{~cm}^{-1}\right)$ moieties. Spectroscopic data of $\mathbf{5}$ were analogous to those of $\mathbf{2}$ with the exception that the resonances for the $\mathrm{C}-1$ methine $\left[\delta_{\mathrm{C}} 45.7 \mathrm{~d}\right]$ were replaced by a tertiary hydroxy at $\mathrm{C}-1\left[\delta_{\mathrm{C}} 70.1 \mathrm{~s}\right]$, which was proved by HMBC correlations (Table 3 ) between $\mathrm{H}-15$ and $\mathrm{C}-1, \mathrm{C}-9, \mathrm{C}-10 ; \mathrm{H}-9$ and $\mathrm{C}-1, \mathrm{C}-15$; and $\mathrm{H}-7$ and $\mathrm{C}-8$, C-6, C-1. The relative stereochemistry of $\mathbf{5}$ was deduced from a 2D NOESY experiment (Table 4), which indicated that $\mathrm{Me}-11, \mathrm{H}-6, \mathrm{H}-2 \beta$, and $\mathrm{Me}-14$ were on one side of the 
Table 3. HMBC Correlations of 1-6

\begin{tabular}{|c|c|c|c|c|c|c|}
\hline $\mathrm{H}$ & 1 & 2 & 3 & 4 & 5 & 6 \\
\hline 1 & & & $C-2,6$ & & & \\
\hline $2 \alpha$ & $C-1,3,10$ & $C-1,4,6$ & & $C-1,4,6$ & & \\
\hline $2 \beta$ & $C-1,3,10$ & $C-1,6$ & & & & \\
\hline $3 \alpha$ & C-4, 5, 11 & C-1, 4,5 & $C-2$ & & & $C-2$ \\
\hline $3 \beta$ & C-4, 5, 11 & C- $-1,4,5$ & & & & $\mathrm{C}-2$ \\
\hline 4 & $C-5$ & & & & & \\
\hline $5 \alpha$ & $C-1,4,7$ & C-1 & C-6 & & $C-4,6,11$ & \\
\hline $5 \beta$ & $C-1,4,7$ & $C-1,6$ & C-6 & & & \\
\hline 6 & C-7 & & & $C-5$ & & \\
\hline $\begin{array}{l}7 \\
8\end{array}$ & $\begin{array}{l}\text { C- } 1,8,12,13,14 \\
\text { C- } 7,9\end{array}$ & $C-1,6,8,12,13,14$ & $\begin{array}{l}\text { C-1, } 6,9,12,13,14 \\
\text { C- } 6,7,9,12\end{array}$ & C- $12,13,14$ & $C-1,6,8,12,13,14$ & $C-6,8,12,13,14$ \\
\hline $\mathrm{OH}-8$ & & & & $C-8,9$ & & \\
\hline 9 & C-15 & & C- $1,7,8,10,15$ & $C-7,8,10$ & C-1, 15 & $C-1,7,15$ \\
\hline 11 & $C-3,4,5$ & $C-3,4,5$ & $C-3,4,5$ & $C-3,4,5$ & $C-3,4,5$ & $C-3,4,5$ \\
\hline $13 z$ & $\mathrm{C}-7,12$ & C-7, 12 & C-12 & & $C-7,12,14$ & C-7, 14 \\
\hline $13_{E}$ & C-7, 8, 12, 14 & C-12, 14 & $C-7,14$ & & C-7, 14 & C-7, 14 \\
\hline 14 & $\mathrm{C}-7,8,12,13$ & C- $7,12,13$ & $\mathrm{C}-7,12,13$ & $C-7,12,13$ & $C-7,12,13$ & $C-7,12,13$ \\
\hline 15 & $C-1,9$ & $C-1,9,10$ & $C-1,6,9,10$ & $C-1,9,10$ & $C-1,9,10$ & $C-1,9,10$ \\
\hline
\end{tabular}

Table 4. NOESY Correlations of 1-6

\begin{tabular}{|c|c|c|c|c|c|c|}
\hline $\mathrm{H}$ & 1 & 2 & 3 & 4 & 5 & 6 \\
\hline $\begin{array}{l}1 \\
2 \alpha \\
2 \beta \\
3 \alpha \\
3 \beta \\
4 \\
5 \alpha \\
5 \beta \\
6 \\
7 \\
8 \\
9 \\
11 \\
13 \mathrm{Z} \\
13_{\mathrm{E}} \\
14 \\
15 \\
\mathrm{OH}-1 \\
\mathrm{OH}-8\end{array}$ & $\begin{array}{l}\mathrm{H}-1,3 \alpha \\
\mathrm{H}-6 \\
\mathrm{H}-2 \beta, 5 \beta, 11 \\
\mathrm{H}-8 \\
\mathrm{H}-7,9 \\
\mathrm{H}-8,15 \\
\mathrm{H}-2 \beta, 6 \\
\mathrm{H}-7,13_{\mathrm{E}} \\
\mathrm{H}-13 \mathrm{Z}, 14 \\
\mathrm{H}-13_{\mathrm{E}} \\
\mathrm{H}-9\end{array}$ & $\begin{array}{l}H-3 \alpha \\
H-11 \\
H-1,5 \alpha \\
\\
H-3 \alpha \\
H-6,11 \\
H-5 \alpha, 11 \\
H-13 \text { Z } \\
\\
H-15 \\
H-2 \beta, 5 \beta, 6 \\
H-7,13_{E} \\
H-13 Z, 14 \\
H-13 E \\
H-9\end{array}$ & $\begin{array}{l}\mathrm{H}-6 \\
\mathrm{H}-5 \beta, 11 \\
\mathrm{H}-9,14 \\
\mathrm{H}-8,15 \\
\mathrm{H}-2 \beta, 6 \\
\mathrm{H}-7,13_{\mathrm{E}} \\
\mathrm{H}-13 \mathrm{Z}, 14 \\
\mathrm{H}-8 \\
\mathrm{H}-1,9\end{array}$ & $\begin{array}{l}\mathrm{H}-3 \alpha, 5 \alpha, 15 \\
\mathrm{H}-2 \beta, 15 \\
\mathrm{H}-2 \alpha, 11 \\
\mathrm{H}-1 \\
\\
\mathrm{H}-5 \alpha, 5 \beta, 11 \\
\mathrm{H}-1,4,7 \\
\mathrm{H}-4,11 \\
\mathrm{H}-11, \mathrm{O}-8 \\
\mathrm{H}-5 \alpha, 8,13^{-} \\
\mathrm{H}-7,9 \\
\mathrm{H}-8,15 \\
\mathrm{H}-2 \beta, 5 \beta, 4,6 \\
\mathrm{H}-7,13_{\mathrm{E}} \\
\mathrm{H}-13_{\mathrm{Z}}, 14 \\
\mathrm{H}-13_{\mathrm{E}} \\
\mathrm{H}-1,2 \alpha, 9 \\
\mathrm{H}-6\end{array}$ & $\begin{array}{l}\mathrm{H}-2 \beta, 3 \alpha, 15 \\
\mathrm{H}-2 \alpha, 6,11 \\
\mathrm{H}-3 \beta \\
\mathrm{H}-2 \beta, 3 \alpha \\
\mathrm{H}-5 \alpha \\
\mathrm{H}-4,5 \alpha \\
\mathrm{H}-4,5 \alpha, 6,11 \\
\mathrm{H}-2 \beta, 5 \beta, 11 \\
\mathrm{H}-13_{\mathrm{Z}}, 5 \alpha \\
\mathrm{H}-15 \\
\mathrm{H}-2 \beta, 5 \beta, 6 \\
\mathrm{H}-7,13_{\mathrm{E}} \\
\mathrm{H}-13^{\mathrm{Z}} \\
\mathrm{H}-2 \alpha, 9\end{array}$ & $\begin{array}{l}\mathrm{H}-2 \beta \\
\mathrm{H}-2 \alpha \\
\mathrm{H}-3 \beta \\
\mathrm{H}-2 \beta, 3 \alpha \\
\mathrm{H}-7 \\
\mathrm{H}-4 \alpha, 5 \beta, 6 \\
\mathrm{H}-5 \alpha, 6, \mathrm{OH}-1 \\
\mathrm{H}-5 \alpha, 5 \beta, 14 \\
\mathrm{H}-4,13 \mathrm{Z} \\
\mathrm{H}-15 \\
\mathrm{H}-3 \beta, 5 \alpha, 5 \beta \\
\mathrm{H}-7,13_{\mathrm{E}} \\
\mathrm{H}-13 \mathrm{Z}, 14 \\
\mathrm{H}-6 \\
\mathrm{H}-9 \\
\mathrm{H}-3 \beta, 5 \beta\end{array}$ \\
\hline
\end{tabular}

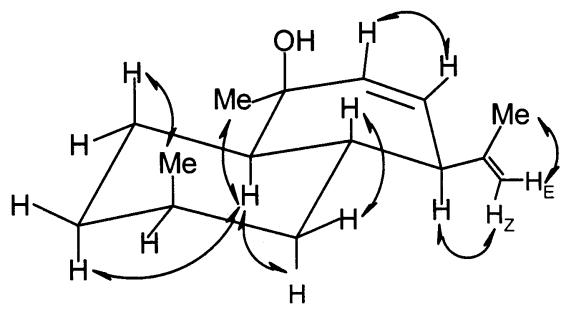

Figure 3. Selected NOESY correlations of $\mathbf{3}$.

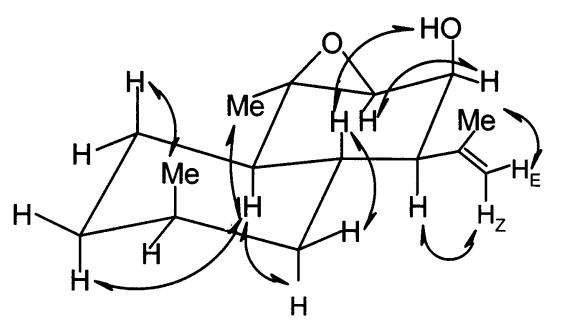

Figure 4. Selected NOESY correlations of 4.

molecule, while $\mathrm{OH}-1, \mathrm{H}-3 \alpha, \mathrm{H}-5 \alpha$, and $\mathrm{H}-7$ were on the opposite side of the molecule. The structure of xenitorin $\mathrm{E}$ is thus formulated as $\mathbf{5}$.

Xenitorin $\mathrm{F}(6)$ has the molecular formula $\mathrm{C}_{15} \mathrm{H}_{24} \mathrm{O}_{2}$, as determined by HREIMS and NMR spectral data (Tables 1 and 2). The IR and UV spectra showed the presence of an $\alpha, \beta$-unsaturated ketone (1655 $\left.\mathrm{cm}^{-1} ; 239 \mathrm{~nm}\right)$ and hydroxyl $\left(3365 \mathrm{~cm}^{-1}\right.$ ) moieties. The NMR spectra of $\mathbf{6}$ were analogous

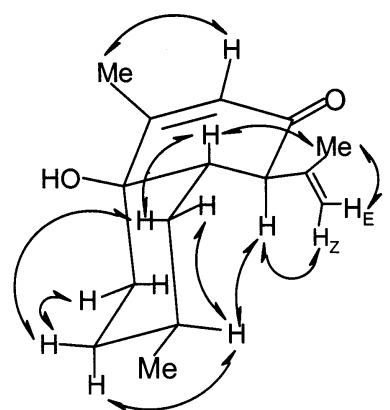

Figure 5. Selected NOESY correlations of 6.

to those of $\mathbf{5}$ except that the ${ }^{13} \mathrm{C}$ NMR chemical shifts for the tertiary hydroxyl and Me-11 were upfield shifted by 13.9 and 4.8 ppm, respectively. An HMBC experiment proved the planar structure to be identical with $\mathbf{5}$. In the NOESY experiment (Figure 5), NOESY correlations from $\mathrm{H}-4$ to $\mathrm{H}-7$ and the absence of NOESY correlations from $\mathrm{H}-6$ to Me-11 proved the cis A/B ring junction and equatorial $(\beta)$ position of $\mathrm{Me}-11$. The structure of xenitorin $\mathrm{F}$ is thus formulated as 6. An attempt at nonenzymatic air oxidation of $\mathbf{2}$ failed to provide a mixture of $\mathbf{5}$ and $\mathbf{6}$.

Xenitorin A exhibited cytotoxicity against A-549 cells with an $E_{50}$ of $0.79 \mu \mathrm{g} / \mathrm{mL}$. Xenitorin E showed cytotoxicty against $P-388$ and $A-549$ cells with $E D_{50}$ 'S of 3.69 and 1.86 $\mu \mathrm{g} / \mathrm{mL}$, respectively. $E D_{50}$ 's of xenitorins $B-D$ and xenitorin $F$ against $\mathrm{P}-388$ and A-549 were higher than $50 \mu \mathrm{g} / \mathrm{mL}$. 


\section{Experimental Section}

General Experimental Procedures. Melting points were determined using a Yanagimoto micromelting point apparatus and are reported uncorrected. Optical rotations were determined on a J ASCO DIP-181 polarimeter. UV spectra were obtained on a Shimadzu UV-160A spectrophotometer, and IR spectra were recorded on a Hitachi 26-30 spectrophotometer. The NMR spectra were recorded on a Bruker Avance 300 NMR spectrometer at $300 \mathrm{MHz}$ for ${ }^{1} \mathrm{H}$ and $75 \mathrm{MHz}$ for ${ }^{13} \mathrm{C}$ or on a Varian Unity INOVA $500 \mathrm{FT}-\mathrm{NMR}$ at $500 \mathrm{MHz}$ for ${ }^{1} \mathrm{H}$ and $125 \mathrm{MHz}$ for ${ }^{13} \mathrm{C}$, respectively, in $\mathrm{CDCl}_{3}$ using TMS as internal standard. EIMS spectra were obtained with a J E OL J MS-SX/ SX 102A mass spectrometer at $70 \mathrm{eV}$. Si gel 60 (Merck, 230400 mesh) was used for column chromatography; precoated Si gel plates (Merck, Kieselgel $60 \mathrm{~F}_{254}, 0.25 \mathrm{~mm}$ ) were used for TLC analysis.

Animal Material. The soft coral $X$. puerto-galerae was collected at Green Island, off Taiwan, in March 2001, at a depth of $6 \mathrm{~m}$ and was stored for 1 month in a freezer until extraction. A voucher specimen, NSUGN-044, was deposited in the Department of Marine Resources, National Sun Yatsen University, Taiwan.

Extraction and I solation. The bodies of the soft coral X. puerto-galerae were freeze-dried to give $0.45 \mathrm{~kg}$ of a solid, which was extracted with $\mathrm{CH}_{2} \mathrm{Cl}_{2}(1.0 \mathrm{~L} \times 3)$. After removal of solvent in vacuo, the residue ( $25 \mathrm{~g}$ ) was chromatographed over Si gel 60 using n-hexane and n-hexane- $\mathrm{CH}_{2} \mathrm{Cl}_{2}$ mixtures of increasing polarity. Elution by n-hexane- $\mathrm{CH}_{2} \mathrm{Cl}_{2}$ (1:3) afforded fractions containing $\mathbf{1}-\mathbf{4}$. Elution by n-hexane- $-\mathrm{CH}_{2-}$ $\mathrm{Cl}_{2}$ (1:5) afforded fractions containing $\mathbf{5}$ and $\mathbf{6}$. Compound $\mathbf{1}$ was further purified by Si gel column chromatography, by eluting with n-hexane-EtOAc (20:1). Compound 2 was further purified by Si gel column chromatography, by eluting with n-hexane-E tOAc (100:7). Compound $\mathbf{3}$ was further purified by Si gel column chromatography, by eluting with n-hexaneEtOAc (12:1). Compound $\mathbf{4}$ was further purified by $\mathrm{Si}$ gel column chromatography, by eluting with n-hexane-EtOAc (9: 1). Compound 5 was obtained by a $\mathrm{C}_{18} \mathrm{HPLC}$ column, by using $\mathrm{MeOH}-\mathrm{H}_{2} \mathrm{O}$ (67:33) as solvent system. Compound 6 was obtained by Si gel column chromatography, by eluting with n-hexane-EtOAc (12:1).

Xenitorin A (1): colorless oil (15 mg); $[\alpha]^{25} \mathrm{D}-39^{\circ}$ (c 0.21 , $\left.\mathrm{CHCl}_{3}\right) ; \mathrm{UV}(\mathrm{MeOH}) \lambda_{\max }(\log \epsilon) 206$ (3.6) nm; IR (KBr) $v_{\max }$ $3400 \mathrm{~cm}^{-1}$; ${ }^{1} \mathrm{H}$ NMR, see Table $1 ;{ }^{13} \mathrm{C}$ NMR, see Table 2; EIMS m/z 220 [M] $^{+}$(27), 203 (12), 187 (32), 175 (71), 162 (39), 149 (79), 136 (40), 123 (64), 109 (100); HREI MS m/z 220.1830 (calcd for $\mathrm{C}_{15} \mathrm{H}_{24} \mathrm{O}, 220.1821$ ).

Xenitorin B (2): col orless amorphous solid (10 mg); $[\alpha]^{25} \mathrm{D}$ $-5.7^{\circ}$ (c 0.20, $\mathrm{CHCl}_{3}$ ); UV (MeOH) $\lambda_{\max }(\log \epsilon) 239$ (3.9) nm; IR (KBr) $v_{\max } 1657 \mathrm{~cm}^{-1} ;{ }^{1} \mathrm{H}$ NMR, see Table $1 ;{ }^{13} \mathrm{C}$ NMR, see Table 2; E I MS m/z 218 [M] ${ }^{+}$(100), 203 (57), 175 (20), 161 (18), 147 (13), 133 (10), 107 (22), 95 (17); HREIMS m/z 218.1671 (calcd for $\mathrm{C}_{15} \mathrm{H}_{22} \mathrm{O}, 218.1665$ ).

Xenitorin C (3): colorless oil (38 mg); $[\alpha]^{25} \mathrm{D}-5.1^{\circ}$ (c 0.12 , $\left.\mathrm{CHCl}_{3}\right)$; UV (MeOH) $\lambda_{\max }(\log \epsilon) 206$ (3.3) nm; IR (KBr) $v_{\max }$ $3436 \mathrm{~cm}^{-1}$; $1 \mathrm{H}$ NMR, see Table 1 ; ${ }^{13} \mathrm{C}$ NMR, seeTable 2; EIMS $\mathrm{m} / \mathrm{z} 220$ [M ] $^{+}$(4), 205 (24), 187 (13), 177 (30), 162 (43), 109 (100); HREIMS m/z 220.1831 (calcd for $\mathrm{C}_{15} \mathrm{H}_{24} \mathrm{O}, 220.1821$ ).

Xenitorin D (4): colorless oil (6 mg); $[\alpha]^{25} \mathrm{D}-39^{\circ}$ (c 0.16 , $\left.\mathrm{CHCl}_{3}\right)$; UV (MeOH) $\lambda_{\max }(\log \epsilon) 209$ (3.7) nm; IR (KBr) $v_{\max }$ $3405 \mathrm{~cm}^{-1}$; ${ }^{1} \mathrm{H}$ NMR, see Table $1 ;{ }^{13} \mathrm{C}$ NMR, see Table 2; EIMS m/z $236\left[^{M}\right]^{+}$(3), 221 (23), 207 (18), 189 (47), 161 (100), 133 (70); HREIMS m/z 236.1781 (calcd for $\mathrm{C}_{15} \mathrm{H}_{24} \mathrm{O}_{2}, 236.1770$ ).
Xenotorin E (5): colorless oil (1 mg); $[\alpha]^{25} \mathrm{D}-10^{\circ}$ (c 0.18 , $\left.\mathrm{CHCl}_{3}\right) ; \mathrm{UV}(\mathrm{MeOH}) \lambda_{\max }(\log \epsilon) 237$ (3.6) nm; IR (KBr) $v_{\max }$ $3450,1650 \mathrm{~cm}^{-1} ;{ }^{1} \mathrm{H}$ NMR, see Table $1 ;{ }^{13} \mathrm{C}$ NMR, see Table 2 ; EIMS m/z 234 [M ]+ (7), 219 (16), 189 (32), 179 (100), 133 (32), 123 (36), 107 (45); HREIMS m/z 234.1626 (calcd for $\mathrm{C}_{15} \mathrm{H}_{22} \mathrm{O}_{2}$, 234.1614)

Xenitorin F (6): colorless oil $(2 \mathrm{mg})$; $[\alpha]^{25} \mathrm{D}+65^{\circ}$ (c 0.22 , $\left.\mathrm{CHCl}_{3}\right) ; \mathrm{UV}(\mathrm{MeOH}) \lambda_{\max }(\log \epsilon) 239$ (3.9) nm; IR (KBr) $v_{\text {max }}$ 3365, 1702, $1650 \mathrm{~cm}^{-1} ;{ }^{1} \mathrm{H}$ NMR, see Table $1 ;{ }^{13} \mathrm{C}$ NMR, see Table 2; EIMS m/z 234 [M] $]^{+}$(22), 218 (38), 204 (15), 192 (23), 180 (100), 168 (84); HREI MS m/z 234.1614 (cal cd for $\mathrm{C}_{15} \mathrm{H}_{22} \mathrm{O}_{2}$, 234.1614)

Cytotoxicity Testing. P-388 cells were kindly supplied by J. M. Pezzuto, Department of Medicinal Chemistry and Pharmacognosy, University of Illinois at Chicago; A549 and HT-29 were purchased from the American Type Culture Collection. Cytotoxic assays were carried out according to the procedure described previously. ${ }^{22}$

Acknowledgment. We thank J . M. Pezzuto, Department of Medicinal Chemistry and Pharmacognosy, College of Pharmacy, University of Illinois at Chicago, for the provision of P-388 cell lines. This work was supported by grants from the National Science Council of Taiwan awarded to C.-Y.D.

\section{References and Notes}

(1) Kashman, Y.; Groweiss, A. J . Org. Chem. 1980, 45, 3814-3824.

(2) Groweiss, A.; Kashman, Y. Tetrahedron 1983, 39, 3385-3396.

(3) Bowden, B. F.; Coll, J . C.; Ditzel, E.; Michell, S. J .; Robinson, W. T. Aust. J. Chem. 1982, 35, 907-1002.

(4) Kitagawa, I.; Kobayashi, M.; Zheng, C.; Kiyota, Y.; Ohnishi, M. Chem Pharm. Bull. 1986, 34, 4590-4596.

(5) Kitagawa, I.; Zheng, C.; Yang, C.; Kobayashi, M.; Kyogohu, Y.; Ohnishi, M. Chem. Pharm. Bull. 1986, 34, 4641-4652.

(6) Bowden, B. F.; Coll, J. C.; Engel hardt, L. M.; Heaton, A.; White, A. H. Aust. J . Chem. 1987, 40, 1483-1489.

(7) Bowden, B. F.; Coll, J . C.; Ditzel, E.; Willis, R. H. Aust. J . Chem 1986, 39, 1717-1722.

(8) I wagawa, T.; Kawasaki, 」.; Hase, T.; Yu, C.; Walter, J . A.; Wright, J. L. C. J . Chem. Soc., Chem. Commun. 1994, 18, 2073-2074.

(9) Kashman, Y.; Saltoun, M.; Rudi, A.; Benayahu, Y. Tetrahedron Lett. 1994, 35, 8855-8858.

(10) I wagawa, T.; Amano, Y.; Hase, T.; Shiro, M. Tetrahedron 1995, 51, $11111-11118$.

(11) I wagawa, T.; Amano, Y.; Hase, T.; Shiro, M. Chem. Lett. 1995, 8, 695696.

(12) I wagawa, T.; Amano, Y.; Nakatani, M.; Hase, T. Bull. Chem. Soc pn 1996, 69, 1309-1312

(13) I wagawa, T: Masuda, T: Okamura, H ; Nakatani, M. Tetrahedron 1996, 52, 13121-13128.

(14) I wagawa, T.; Kawasaki, J ; Hase, T., Wright, J . L. C. Tetrahedron 1997, 53, 6809-6816.

(15) I wagawa, T.; Kawasaki, J .; Hase, T. J . Nat. Prod. 1998, 61, 15131515.

(16) Kawasaki, J .; Amano, Y.; Okamura, H.; Nakatani, M.; Hase, T. Heterocycles 1996, 43, 1271-1278.

(17) I wagawa, T.; Nakamura, K.; Hirose, T.; Okamura, H.; Nakatani, M. . Nat. Prod. 2000, 63, 468-472.

(18) Miyaoka, H.; Nakano, M.; I guchi, K.; Yamada, Y. Tetrahedron 1999, 55, 12977-12982

(19) Miyaoka, H.; Mitome, H.; Nakano, M.; Yamada, Y. Tetrahedron 2000, 56, 7737-7740

(20) Kobayashi, M : Zheng, C: Y Yang C: Kyogohu, Y : Kitagawa, I. Chem Pharm. Bull. 1986, 34, 4641-4652. Kobayashi, M.; Zheng, C.; Yang, C.; Kyogohu, Y.; Kitagawa, I. Chem. Pharm. Bull. 1986, 34, 46414652

(21) Geran, R I.; Greenberg, N. H.; MacDonald, M. M.; Schumacher, A. M.: Abbott, B. J. Cancer Chemother. Rep. 1972, 3, 1-91.

(22) Hou, R.-S.; Duh, C.-Y.; Chiang, M. Y.; Lin, C.-N. J . Nat. Prod. 1995 58, 1126-1130.

NP0203281 